\title{
How Will the Future Be? The Transformation of Romanian Labour Legislation in a Global Context
}

\author{
Nasıl Bir Gelecek? Küresel Bağlamda Romanya İş Hukukunun Dönüşümü
}

\author{
MAGDOLNA VALLASEK ${ }^{*}$ \\ * Dr. Senior Lecturer, Sapientia Hungarian University of Transylvania, Department of Law, Cluj-Napoca, \\ Romania, E-mail: mvallasek@kv.sapientia.ro \\ (D) https://orcid.org/0000-0003-4745-2218
}

\begin{abstract}
Over the past two decades, it has become increasingly common to hear the verdict that labour law is in crisis, finding it increasingly difficult to fulfil its main task of protecting workers. This is happening first and foremost because since classical labour law rules were established, society as a whole has undergone a profound change, with the labour market shifting towards production and the economy, globalisation, digitalisation and flexible work. Following the 4.0 industrial revolution, the aim is to achieve a 5.0 society, and this is the direction artificial intelligence, digitalisation and robotisation point to as well. In our short study, we ask to what extent labour law is ready for this, and what are the main problems and obstacles that may arise. We do this by taking the example of Romania's legal development, and starting from the premise that the labour law measures introduced in the wake of the current pandemic are a valuable experience, as they have acted as a catalyst to bring to the fore dilemmas that labour law has been struggling with for some time. We can therefore experiment with the effects of some of the measures introduced in the context of the pandemic on the labour market and the situation of workers, and it would be wise to learn from these experiences.
\end{abstract}

Keywords: Labour law, Flexicurity, Digitalization, Work-life balance, Romania

Öz: Son yirmi yılda, iş kanununun krizde olduğu ve bu nedenle işçileri koruma ana görevini yerine getirmesinin giderek zorlaştığı iddiası yaygın hale gelmiştir. Bu her şeyden önce klasik iş hukuku kuralları oluşturulduğundan beri, işgücü piyasasının üretime ve ekonomiye, küreselleşmeye, dijitalleşmeye ve esnek çalışmaya doğru kaymasıyla birlikte toplumun bir bütün olarak derin bir değişim geçirmesinden kaynaklanmaktadır. 4.0 sanayi devriminin ardından amaç 5.0 toplumuna ulaşmaktır ve yapay zeka, dijitalleșme ve robotlaşmanın da gösterdiği yön budur. Kısa çalışmamızda iş kanununun buna ne kadar hazır olduğunu, ortaya çıkabilecek başlıca sorun ve engellerin neler olduğunu sorguluyoruz. Bunu, Romanya'nın yasal gelişimini örnek alarak ve mevcut pandemi sonrasında uygulamaya konulan iş kanunu önlemlerinin değerli bir deneyim olduğu varsayımından yola çıkarak yapıyoruz. Nitekim hukuk, bir süredir bu sorunlarla yoğun biçimde uğraşmaktadır. Bu nedenle, pandemi bağlamında getirilen bazı önlemlerin işgücü piyasası ve işçilerin durumu üzerindeki etkilerini incelemek ve bu deneyimlerden ders almak akıllıca olacaktır.

Anahtar kelimeler: Iş̧ hukuku, Esnek güvence, Dijitalleşme, İşyaşam dengesi, Romanya 


\section{Introduction}

The pace of change in our world seems to have accelerated in recent decades, and this is not anything new. Change is the new constant, it is the measure of our individual and collective existence, by which we try to be present in the present, plan our tomorrows, dream our futures. We seek security amidst the forces of change and stability that so often oppose each other. While a few years ago we were talking about the 4th industrial revolution (Industry 4.0), today we are talking about the realisation of the 5.0 society, a society that creates a new paradigm of cooperation and interaction between machines and humans. At first sight, the task seems contradictory: to create a human-faced society in a world of machines. "Society 5.0 is a people-centric society that resolves both economic and social issues while ensuring that people live comfortable and fulfilling lives." But how? The answers are not yet clear, and in our diverse and polarised world, where the hi-tech smart city and extreme poverty, the digital natives and the functional or completely illiterate coexist, it is unlikely that answers will be easy to come by.

The role of the instruments of law is to regulate the background to change, but we must also recognise that rapid developments often result in regulation lagging behind social realities. This is why it would be of paramount importance for legislators to develop a regulatory framework for the functioning of society based on medium and long-term strategies, and also facilitate a rapid reaction time whenever a new situation requires immediate intervention. The need for this is much more salient in some areas of the law, because while we have legal norms based on stable or slowly changing social norms, in other cases the primary task of the law is to respond to and create norms for real, changing social situations. It is our conviction that this is particularly true in the case of labour law, social law and social security, where the weakening of workers' rights and the loss of security can be the result of the fact that everyday realities and legal norms start to exist in parallel realities.

\section{The World of Work in a Changing World}

The labour market is the pulse of society. What characterises a state's labour market is closely linked to its social, economic and political situation. Labour law can never be examined on its own, separate from the realities of society, but only as it integral part. We have seen this all over the world in particular during the recent pandemic. Prominent labour law scholars have long argued that labour law is in a crisis, it is subject to a transformation that must lead to a regulation that is more reflective of current social, economic and production realities, in order for labour law to continue to fulfil its essential role. Looking at the evolution of labour legislation, not only in Romania or in the countries of the European Union, but also globally, we can see that labour law is plagued by many contradictions. On the one hand, it has become inevitable that labour law, which has traditionally been dominated by national regulation, should increasingly focus on the international system of regulations, as the international or global labour market is playing an increasing role alongside national labour markets, in line with the production and economic situation. ${ }^{2}$ On the other hand, the fact that labour law is in crisis because

${ }^{1}$ Atshusi Deguchi et al., "Solving Social Issues through Industry - Academia Collaboration”, Society 5.0. A People-centric Super-smart Society, Hitachi-UTokyo Laboratory: Springer Open, 2020, p.86.

${ }^{2}$ Bob Hepple, Labour Laws and Global Trade, Oxford and Portland, Oregon: Hart Publishing, 2005. 
the system of labour relations has changed or is changing all over the world and classical labour law can no longer keep up with it, and therefore an urgent review is needed, is becoming more and more strongly stated. ${ }^{3}$ However, the transformation of labour law must not lose sight of its primary objective, which is to protect the employee, who is always at a disadvantage in relation to the economic and therefore bargaining power and bargaining position of the employer. ${ }^{4}$ This is a particularly neuralgic issue in cases of forms of employment and work which are already pushing the boundaries of labour law, or which currently do not even fit under the protective umbrella of labour law, i.e., the so-called atypical forms of employment.

The urgent and topical dilemmas of the world of work are addressed from a variety of perspectives, not only by lawyers with a keen interest in the subject, but also by renowned philosophers, economists and other experts. According to Byung-Chul Han, a South Korean-born philosopher living in Germany, for example, a new world seems to be emerging in which society (or, let us add, the part of society that needs it) is under the absolute power of the necessity to work, and the only but essential difference since the Industrial Revolution is that the man of the modern society does not subject its life to the external but to the internal compulsion to work, to the compulsion to perform. ${ }^{5}$ David Graeber in his book Bullshit Jobs. A Theory ${ }^{6}$, or David Freyne in The Refusal of Work ${ }^{7}$, argue that we live in a workbased society today, where countless hours are wasted on work that is often completely unnecessary and of no benefit to society. We do all this in a context that, as the result of technological and communicative developments, keeps us almost constantly on the alert, inextricably confusing our private lives with our working lives, the external need to acquire the material resources necessary for subsistence with some deep, internal need to feel "useful".

Labour legislation seems to reflect these trends, with employment flexibility gaining prominence, often referred to as the key to work-life balance, but often at the expense of workers' social security, and with its many other drawbacks increasingly visible beneath the surface of a beautiful future. They already exist in the present, and the future will unquestionably bring with it forms of work that maximise this flexibility, while taking advantage of the opportunities that under-regulation can bring to the detriment of those who do the work. Meanwhile, and we must not forget this, the starting point remains that the employment relationship is the cornerstone of society and of modern labour law. ${ }^{8}$

\footnotetext{
${ }^{3}$ Simon Deakin, "The Comparative Evolution of the Employment Relationship", Boundaries and Frontiers of Labour Law. Goals and Means in the Regulation of Work, eds., Guy Davidov and Brian Langille, Oxford and Portland, Oregon: Hart Publishing, 2006, p.101.

${ }^{4}$ Paul Davies and Mark Freedland, Labour and the Law, Oxford University Press, 1983.

${ }^{5}$ Byung-Chul Han, The Burnout Society, Budapest: Typotex, 2019, p.26-27.

${ }^{6}$ David Graeber, Bullshit Jobs: A Theory, London: Penguin Books, 2018.

${ }^{7}$ David Freyne, The Refusal of Work, London: Zed Books, 2015.

${ }^{8}$ Simon Deakin, The Many Futures of The Contract of Employment, University of Cambridge: ESRC Centre for Bussines Reserach, 2000, p.10.
} 


\section{The Transformation of Labour Law and the Romanian Case in a Global Context}

\section{The Premises of Change: Flexicurity and Digitalisation}

The development of labour law in Romania is also strongly influenced by global trends and, as a member state of the European Union, by Community labour law. Numerous measures have also been taken recently to counter the negative effects of the pandemic on the labour market, and although it is still too early to analyse the results of some of these measures, it can be concluded that the trend is indeed towards the previously identified need for flexibility. As a kind of preliminary conclusion, we can already say that the pandemic has not really brought new problems to the surface, but it has revealed and made inescapable the depths and nuances of factors already known at this stage of labour law development, which it is essential to address. In short, they have been the catalyst for change, for certain processes that have been going on for a long time. The most obvious of these are the increase in teleworking and working from home, the rise of digitalisation in labour law, and the parallel increase in the flexibility and, in many cases, simplification of labour law. Although we do not intend to deal with this subject in our study, it is also necessary to note that, in parallel with the changes in individual labour law, in Romania and in many other European countries, we are witnessing the marginalisation of collective labour law, the effectiveness of negotiations between the social partners is decreasing and the scope of workers' collective bargaining instruments is weakening.

While in the last year home office was the most talked about term of employment, in the years before flexicurity was the prominent term in the labour law of European countries, and indeed the much talked about home office in the context of the pandemic is also best interpreted in the context of flexicurity. The definition of flexicurity is relatively simple. As the European Union understands it, "flexicurity is an integrated strategy for enhancing, at the same time, flexibility and security in the labour market. It attempts to reconcile employers' need for a flexible workforce with workers' need for security - confidence that they will not face long periods of unemployment." The basic principles of flexicurity are based on four pillars that are considered necessary to achieve a sufficiently flexible but safe work. These are the following: effective labour market policies, flexible and reliable contractual arrangements, comprehensive lifelong learning strategies and modern and adequate social protection systems. Member states of the European Union, including Romania, whose accession in 2007 roughly coincides with the development of flexicurity, have committed themselves to bringing their labour law provisions in line with this set of rules. The idea is potent and seems to be effective. But the path to implementation is not straightforward and simple. Today, a decade and a half later, it is still not clear exactly where the golden ratio between flexibility and security lies. It should be added that there is plenty of criticism of the flexicurity model.

Already when the rules of flexicurity were being drafted, Keune and Jepsen pointed out that the main pitfall of this sound idea could be that it does not pay enough attention to protecting workers' rights. "The Commission presents flexicurity as a new way of dealing with the globalized economy, as a new and balanced approach

\footnotetext{
9 European Commission, "Flexicurity", last accessed June 18, 2021, https://ec.europa.eu/social/main.jsp? catId=102\&langId=en \&.
} 
to create the flexibility needed by enterprises while at the same time providing security to workers. However, disentangling the Commission's position shows that its concept of flexicurity is not balanced and hardly new. It is not balanced because, instead of creating a win-win situation, it favours flexibility over security and employers' interests over workers' interests. It is not new since all major elements of the Commission's flexicurity vision have been part of its labour market discourse and of the EES (European Employment Strategy, a. n.) for quite some years already. The Commission's flexicurity position also confirms its emphasis on economic instead of social goals and its reconceptualisation of security from protection against risk to the capacity to adapt to change, and of solidarity from redistributive solidarity to competitive solidarity. What is new, however, is that flexicurity seems to be gradually replacing the broader EES and represents a narrowing down of European employment policy." 10

Janssen lists similar concerns when analysing OECD data and concludes that in the case of Denmark, cited as a model state for flexicurity, the positive factors are actually due to a good collective bargaining system and strong passive and active labour market policies. ${ }^{11}$

Jorgensen and Madsen, in their analysis of flexicurity, put the dilemma of many very succinctly. "Such an impressive list of promises calls for scepticism. It is therefore not surprising that some political actors and representatives from the social partners - especially from the trade unions - have expressed serious doubt about the validity of the concept. Is flexicurity in reality a Trojan horse designed to abolish traditional job protection and thus remove some of the victories won by European workers and their organisations over during the 20th century?"12

Flexicurity as a panacea is certainly not a realistic idea, but it is also true that we do not have a better strategy at the moment. Regulation that reflects the realities of the labour market, production and technology is also important because it allows as many workers as possible to be brought under the umbrella of labour law. We think the key is how we put the principles of flexicurity into practice, how we give it substance, and how we do that can vary from country to country, taking into account a myriad of objective factors. The ways of achieving flexibility, which is also a criterion of security, must therefore be interpreted flexibly.

One of the catalysts for more flexible working relationships and the growing demand for this is digitalisation and robotisation, bringing new technological advances into the battle for production and economic growth. However, this is a much older phenomenon than the emergence of the 5.0 society, and one that has been seen in the analysis of the 4.0 industrial revolution as a phenomenon that should be familiar to us since the first steam engines were used. The related fears about the labour market, employment and unemployment are the same, but their extent and nature have changed. As Guy Ryder, ILO Director-General put it, "[F]ears about the impact of technology on the labor market are nothing new. In

\footnotetext{
${ }^{10}$ Maarten Keune and Maria Jepsen, Not Balanced and Hardly New: The European Commission's Quest for Flexicurity, Brussels: ETUI-REHS, 2007, p.16-17.

${ }^{11}$ Ronald Janssen, "Flexicurity: The Model That Never Was", Social Europe Journal, December 6, 2013, last accessed 18 June, 2021, http://gesd.free.fr/flexijan.pdf.

${ }^{12}$ Henning Jorgensen and Per Kongshoj Madsen, "Flexicurity and Beyond - Reflections on the Nature and Future of a Political Celebrity”, Flexicurity and Beyond: New Agenda for the European Social Model, eds., Henning Jorgensen and Per Kongshoj Madsen. Copenhagen: DJF, 2007, p.8.
} 
the early nineteenth century, a group of English textile workers known as the Luddites worried that new technologies like power looms and spinning frames would cost them their jobs. They protested by smashing the machines. Today, anxiety that new technologies could destroy millions of jobs is as high as ever." ${ }^{13}$ But it is now clear that smashing machines in protest will not turn back the wheel of history and progress. But there are lessons to be learned from the past and it should be seen as a model for solving problems. ${ }^{14}$

The impact of digitalisation on the labour market obviously cannot be ignored, but let us add that digitalisation is only part of the picture, there are countless other factors that influence the functioning of the labour market. "This is why the relationship between computerisation and jobs is and will remain complex and resistant to reductionist analysis. Trends which look likely to be amplified by the digital economy include the emergence of a wide variety of flexible and non-standard forms of work, since digital technologies - and particularly the combination of big data modelling with human or object geolocation - will continue to facilitate and speed up the introduction of flexible working arrangements. Finally, digitisation will not give rise to any changes in respect of the central role played by work in the construction of individual and collective identity or the social recognition associated with work, but it will sweep away some of its fundamental tenets, in particular the bonds of social contact which are forged and the landmarks in space and time which provide it with a unique position in social life." ${ }^{15}$

\section{The Responses of Romanian Labour Law to the Challenges of Digitalisation and the Need for Flexibility}

Romania has been a Member State of the European Union since 2007 and its current legislation is largely determined by the obligation to apply Community law. Romanian labour law cannot exclude itself from international and European trends, and therefore the last decade and a half has been strongly influenced by the discourse and legislative process on the transformation of labour law and its flexibilisation. Meanwhile, Romania has (had) to overcome a situation in which it was the EU country with the highest poverty risk for workers, proving the fact that the existence of a job is no guarantee that a person will not fall below the poverty line. ${ }^{16}$

Romanian labour law is based on the Labour Code (Law 53 of 2003) adopted in 2003, which has since undergone numerous amendments and additions, which is obviously unfortunate for a piece of legislation of such importance; these were however essential in a rapidly changing field such as labour law if we do not want to have a parallel reality between regulation and social reality. In the case of the interventions in the normative text of the Labour Code, the buzzword has always been the much-vaunted flexicurity, and all the changes that have taken place basically point in this direction. Nevertheless, in our assessment, the domestic legislation can be considered as a good practice for the time being, because although the

\footnotetext{
${ }^{13}$ Guy Ryder, "Labor in the Age of Robots", Social Europe, February 27, 2015, https://socialeurope.eu/laborin-the-age-of-robots.

${ }^{14}$ Nouriel Roubini, “Will Technology Destroy Jobs?”, Social Europe Journal, Social Europe, January 14, 2015, https://socialeurope.eu/technology-2.

${ }^{15}$ Gérard Valenduc and Patricia Vendramin, "Work in the Digital Economy: Sorting the Old from the New", Working Paper 2016.03, Brussels: ETUI, 2016, p.45.

${ }^{16}$ Social Europe, Many Ways, One Objective: Annual Report of the Social Protection Committee on the Social Situation in the European Union, Luxembourg: Publications Office of the European Union, 2014, p.36.
} 
most recent interventions justified by the pandemic crisis management are not always well thought out, the overall text of the law tries to strike a balance between the security of workers and the needs of employers seeking a more flexible direction.

The Romanian labour law has been moving towards more flexible regulation for almost a decade, since Law No 40 amending the Labour Code entered into force in 2011, with the aim of making the Romanian labour law more flexible, in line with the needs of the labour market and the international trends, as explained in detail in the explanatory memorandum. The Romanian legislation does not define the parameters of flexibility, nor what is considered as typical or atypical employment, but an analysis of the legislation leads us to the conclusion that, as a general rule, only employment relationships based on a full-time employment contract of indefinite duration can be considered as "typical" employment relationships. Any other form of employment is therefore considered "atypical" Of these atypical forms of employment, however, only part-time and fixed-term employment, temporary agency work and working from home are regulated in the Labour Code This is complemented by the provisions on teleworking, regulated in a separate law, Act 81 of 2018, or even day-rate labour, which is on the fringes of labour law and which is regulated by Act 52 of 2011, Atypical employment is obviously much more widespread in practice, but new and innovative forms of employment are currently outside the scope of national, and in many cases international, labour law. We can talk here about labour performed as crowdwork or crowdsourcing, appbased work, and all the novel forms of work that are relatively new in practice and specific to the gig economy. In the absence of agreed definitions and clear methodological tools, its dimensions are difficult to quantify even on a global scale, and official labour market statistics are scarce ${ }^{.17}$ at the same time, in Romania, people working in this way are completely outside the protective umbrella of labour law. The share of atypical forms of work in total employment is still rather low. In the 2020 Romania Country Report, the two most commonly used atypical forms of employment also have relatively low take-up rates. Between 2014 and 2019, the proportion of fixed-term contracts was just 1.1-1.5\%, while the proportion of parttime contracts ranged between 8.8-6.3\%, with a clear downward trend ${ }^{18}$. The proportion of working from home was only $0.4 \%$ in 2018 , the year the telework law came into force, according to EUROSTAT data, and this has reached $0.8 \%$ after the first year of the law's application and presumably already due to its impact. ${ }^{19}$ With these values, Romania was among the last among the EU Member States.

Among the crisis management measures for pandemic COVID-19 worldwide, the transfer of workers to telework was a priority, wherever possible. In Romania, similar measures were already introduced in March 2020, first only in the form of a recommendation by the Ministry of Labour, and then at the normative level with the entry into force of Decree No 195 of 2020. At the time of writing, the special legal regime is still in force, the state of emergency has been extended for another

\footnotetext{
${ }^{17}$ Agnieszka Piasna, "Counting Gigs: How can We Measure the Scale of Online Platform Work", European Trade Union Institute, Working Paper, 2020.06, Brussels, 2020, p.17.

${ }^{18}$ European Commission, Country Report Romania 2020, Bruxelles, 26.2.2020, SWD (2020) 522 final, last accessed 15 February, 2021, https://eur-lex.europa.eu/legal-content/RO/TXT/PDF/?uri=CELEX:52020SC0522\&from=EN. ${ }^{19}$ Eurostat, "Working from Home in EU", 20 June, 2018, last accessed 15 February, 2021, https://ec.europa.eu/eurostat/web/products-eurostat-news/-/DDN-20180620-1.
} 
month, and there are likely to be further extensions. With reference to this extraordinary situation, there have recently been several rapid interventions in labour law, which, although justifiable, were not sufficiently well thought out and were not brought into line with the norms and spirit of the Labour Code as a whole. It is beyond the scope of this study to analyse these, but as an example, we will mention the new possibility of concluding employment contracts electronically, introduced by Emergency Government Ordinance No 36 of 2021, which also meets the requirements of digitalisation. While the amendment has indeed introduced a simpler option that complies with the rules of social distancing, the obligation for the employer to provide a copy of the written contract to the employee before the start of employment remains unchanged, and there is no clarification on whether this is possible in electronic form, for example by email. Perhaps we are not wrong to see the above example as proof that, although it is undoubtedly possible in emergency circumstances, it is not advisable to amend a complex organic law such as the Labour Code by means of an emergency government ordinance.

\section{Shades and Shadows on the Margins of Trends in the Development of Labour Law}

The measures introduced in the wake of the pandemic have accelerated the development of labour law, shifting it towards more flexible forms of work and greater use and exploitation of digitalisation. In this sense, this period can also be seen as a kind of testing ground, as the forced circumstances have brought to the fore many of the problems that experts have been warning about for some time. We can see the shades and shadows more clearly than ever before, and that is good, because it allows us to make corrections if there is proper determination to do so. The potential pitfalls of flexible work are not new, and we have seen in the past that warnings have been formulated about flexicurity since it was first developed. In this respect, the issue of work-life balance, the situation of women workers, the differences between different groups of workers, in short, the management of inequalities in different areas, deserves particular attention. The rise of digitalisation is reinforcing these very inequalities. As Henning Meyer put it, "[T] he key problem for policy making is that these technology driven developments are certain to further increase existing inequalities and to create new ones at a time when, (...), we have already returned to historically high levels." ${ }^{20}$

Inequalities between groups of workers are sharply marked for female and male labourers. "When discussing the pros and cons of the digital revolution, we also have to take into account that flexible working impacts on women's and men's lives differently. With flexible working time, men often invest more time in work. Women, by contrast, use their time flexibility more for activities and duties outside work." ${ }^{21}$ Consequently, women are significantly more exposed to the risk of the overlap between work and personal time, which is one of the most talked about downsides of flexible working in general. One of the reasons for this is the inadequate regulation of work time scheduling and record-keeping, which is a major

\footnotetext{
${ }^{20}$ Henning Meyer, "The Work and Inequality Challenge of the Digital Revolution: How Should Governments Respond?”, Social Europe, August 13, 2015, https://socialeurope.eu/the-work-and-inequality-challenge-ofthe-digital-revolution-how-should-governments-respond.

${ }^{21}$ Yvonne Lott, “The Need for a Gender Perspective on Digitalization", Social Europe, August 5, 2015, https://socialeurope.eu/need-gender-perspective-digitalization.
} 
difficulty in the case of teleworking and working with digital devices. "The organisation of work is also changing: some people work in their free time because they are asked to, some because they feel expected to do so and some because they just want to, while some can work pretty much anywhere, anytime using information and communications technology (ICT). More ICT mobile workers (26\%) report poor work-life balance than other workers (18\%)." 22 In a context where working anytime and anywhere has become possible, the benefits of flexibility have come at a price. "Once more, the outcomes appear to be ambiguous: although T/ICTM workers can use working remotely to improve their work-life balance, they are also at greater risk of working in their free time (their non-paid work time) and reported 'blurring' between paid work and other personal commitments, such as family responsibilities." ${ }^{23}$ Leovaridis and Nicolăescu, analysing the situation in the countries of the European Union and highlighting the characteristics of Romania, also conclude that although flexible work should theoretically be more beneficial for some workers, it is precisely for those with young children, especially women, that it creates inequalities and imbalances between work time - rest and private life. $^{24}$

These inequalities have become even more visible in the light of the experiences gained in the context of the pandemic. It is clear, for example, that the use of digitalisation and the shift to teleworking is not feasible for those groups of workers who are already the most exposed to labour market changes, who are most at risk of unemployment or who are in the most difficult jobs (precarious work) due to their lack of education. ${ }^{25} \mathrm{~A}$ similar lesson learnt is that there is a generational difference in workers' perceptions of the impact of digitalisation on their work. Examples from two neighbouring EU Member States, Romania and Hungary, show that young workers in the 20-29 age group prefer more flexible forms of work, teleworking and believe that work-life balance can be found in such circumstances as well. However, the picture is nuanced by the fact that the respondents had a tertiary education and some had no real experience of teleworking. ${ }^{26}$

\section{Conclusions}

So where is labour law heading and where can it go on the threshold of society 5.0 ? The question is not without relevance, even if, in our view, what we call society 5.0, although it may be a model, is still a long way off. Confronting labour law with the realities of our everyday lives, on the other hand, is essential and needs to start now. These challenges revolve around digitalisation, the spread of atypical work and deep inequalities between groups of workers, and are waiting for solutions. However, the starting point, whatever it may be, must remain the same as the essential

\footnotetext{
${ }^{22}$ Agnes Parent-Thirion, "Working Hours are Decreasing, So Does Work-Life Balance Still Matters?", Foundation Focus, (Special Issue: Work-Life Balance: Creating Solutions for Everyone), 19 (2016), p.3.

${ }^{23}$ Eurofound-International Labour Office, Working Anytime, Anywhere: The Effects on the World of Work, Geneva, 2017, p.29-30.

${ }^{24}$ Cristina Leovaridis and Andreea Nicolăescu, "Raportul viață profesională - viață privată, preocupare de actualitate a UE în domeniul pieței muncii”, Revista Română de Sociologie, 22 (2011), p.108-122.

${ }^{25}$ Andy Hodder, "New Technology, Work and Employment in the Era of COVID-19: Reflecting on Legacies of Research", New Technology, Work and Employment, 35/3 (2020), p.262-275. Radhicka Kapoor, "The Unequal Effects of the Covid-19 Crisis on the Labour Market”, The India Forum, August 7, 2020, last accessed 15 May, 2021, https://www.theindiaforum.in/article/unequal-effects-covid-19-crisis-labour-market.

${ }^{26}$ Musinszky Zoltán et al., "Workaholism and a New Generation - Labour Market Survey among Hungarian and Romanian Youth”, Amfiteatru Economic, 22/14 (2020).
} 
feature of labour law: the protection of the weaker party in the employment relationship, and that weaker party is, of course, the employee. "Labour law, being itself a reaction to a social problem, has been an instrument for the protection of a weak subject in the market, thus fulfilling a distributive function. Its main regulatory technique has been the substitution of contractual freedom by state or collective regulation, which defines the content of employment contracts. Through regulation it has tried to modify the market's rules, correcting its operation by including the social objectives and concerns which had been historically absent." ${ }^{27}$ Flexicurity, which the countries of the European Union are trying to follow, is not a panacea for everything, as we have seen, and there are many doubts about how it works. "The market regulation perspective is represented in the concept of "flexicurity". In this guise, the role of employment law is to contribute to the fair and efficient functioning of labour markets. As such, the principle of equal treatment can be freely shaped to reflect the desired flexicurity combination." 28

As long as we believe, and we must believe, that it is its task to protect the employees in an unequal employment relationship, there is no other way for labour law to go than to find solutions that can provide this protection, flexibly or, shall we say, taking into account social realities.

\section{References}

Bell, Mark. "Between Flexicurity and Fundamental Social Rights: The EU Directives on Atypical Work". European Law Review. 37/1 (2012): 31-48.

Bravo-Ferrer, Miguel Rodriguez-Pinero and Miguel Rodriguez-Pinero Royo. "The Role of Labour Law and Industrial Relations in Job Creation Policies”. Job Creation and Labour Law: From Protection towards Pro-Action. Ed. Marco Biagi. Dordrecht/London/Boston: Kluwer Law International, 2000.

Davies, Paul and Mark Freedland. Labour and the Law. Oxford University Press, 1983.

Deakin, Simon. "The Comparative Evolution of the Employment Relationship". Boundaries and Frontiers of Labour Law. Goals and Means in the Regulation of Work. Eds., Guy Davidov and Brian Langille. Oxford and Portland, Oregon: Hart Publishing, 2006.

Deakin, Simon. The Many Futures of The Contract of Employment. University of Cambridge: ESRC Centre for Business Research, 2000.

Deguchi, Atshusi, Yasunori Akashi, Eiji Hato, Junichiro Ohkata, Taku Nakano and Shin'ichi Warisawa. "Solving Social Issues through Industry-Academia Collaboration”. Society 5.0. A People-centric Super-smart Society, HitachiUTokyo Laboratory: Springer Open, 2020.

Eurofound-International Labour Office. Working Anytime, Anywhere: The Effects on The World of Work. Geneva, 2017.

European Commission. "Flexicurity". Last accessed June 18, 2021. https://ec.europa.eu/social/main.jsp?catId=102\&langId=en\&.

\footnotetext{
${ }^{27}$ Miguel Rodriguez-Pinero Bravo-Ferrer and Miguel Rodriguez-Pinero Royo, "The Role of Labour Law and Industrial Relations in Job Creation Policies", Job Creation and Labour Law: From Protection towards ProAction, Ed. Marco Biagi, Dordrecht/London/Boston: Kluwer Law International, 2000, p.11.

${ }^{28}$ Mark Bell, "Between Flexicurity and Fundamental Social Rights: the EU Directives on Atypical Work", European Law Review, 37/1 (2012), p.31-48.
} 
European Commission. Country Report Romania 2020. Bruxelles, 26.2.2020, SWD (2020) 522 final. Last accessed 15 February, 2021, https://eur-lex.europa.eu/ legal-content/RO/TXT/PDF/?uri=CELEX:52020SC0522\&from=EN.

Eurostat. "Working from Home in EU". June 20, 2018. Last accessed February 15, 2021. https://ec.europa.eu/eurostat/web/products-eurostat-news/-/DDN-20180620-1.

Freyne, David. The Refusal of Work. London: Zed Books, 2015.

Graeber, David. Bullshit Jobs: A Theory. London: Penguin Books, 2018.

Han, Byung-Chul. The Burnout Society. Budapest: Typotex, 2019.

Hepple, Bob. Labour Laws and Global Trade, Oxford and Portland, Oregon: Hart Publishing, 2005.

Hodder, Andy. "New Technology, Work and Employment in the era of COVID19: Reflecting on Legacies of Research". New Technology, Work and Employment. 35/3 (2020): 262-275.

Janssen, Ronald. "Flexicurity: The Model That Never Was". Social Europe. December 6, 2013. Last accessed 18 June, 2021. http://gesd.free.fr/flexijan.pdf.

Jorgensen, Henning and Per Kongshoj Madsen. "Flexicurity and Beyond Reflections on the Nature and Future of a Political Celebrity". Flexicurity and Beyond: New Agenda for the European Social Model. Eds., Henning Jorgensen and Per Kongshoj Madsen, Copenhagen: DJF, 2007.

Kapoor, Radhicka. "The Unequal Effects of the Covid-19 Crisis on the Labour Market”. The India Forum. August 7, 2020. https://www.theindiaforum.in/ article/unequal-effects-covid-19-crisis-labour-market.

Keune, Maarten and Maria Jepsen. Not Balanced and Hardly New: The European Commission's Quest for Flexicurity. Brussels: ETUI-REHS, 2007.

Leovaridis, Cristina and Andreea Nicolăescu. "Raportul Viață Profesională - Viață Privată, Preocupare De Actualitate A UE În Domeniul Pieței Muncii”. Revista Română de Sociologie. 22 (2011).

Lott, Yvonne. "The Need for a Gender Perspective on Digitalization". Social Europe. August 5, 2015. https://socialeurope.eu/need-gender-perspectivedigitalization.

Meyer, Henning. "The Work and Inequality Challenge of the Digital Revolution: How Should Governments Respond?". Social Europe Journal. August 13, 2015. https://socialeurope.eu/the-work-and-inequality-challenge-of-the-digitalrevolution-how-should-governments-respond.

Musinszky, Zoltán, Magdolna Vallasek, Gábor Mélypataki, Erika Horváthné Csolák and Katalin Lipták. "Workaholism and a New Generation-Labour Market Survey among Hungarian and Romanian Youth". Amfiteatru Economic. 22/14 (2020): 1227-1242.

Parent-Thirion, Agnes. "Working Hours Are Decreasing, So Does Work-Life Balance Still Matters?". Foundation Focus. (Special Issue: Work-Life Balance: Creating Solutions for Everyone), 19 (2016): 3-4,

Piasna, Agnieszka. "Counting Gigs: How Can We Measure The Scale Of Online Platform Work". European Trade Union Institute, Working Paper 2020.06. Brussels, 2020.

Roubini, Nouriel. “Will Technology Destroy Jobs?”. Social Europe. January 14, 2015. https://socialeurope.eu/technology-2. 
Ryder, Guy. "Labour in the Age of Robots". Social Europe. February 27, 2015. https://socialeurope.eu/labor-in-the-age-of-robots.

Social Europe. Many Ways, One Objective: Annual Report of the Social Protection Committee on the Social Situation in the European Union. Luxembourg: Publications Office of the European Union, 2014.

Valenduc, Gérard and Patricia Vendramin. "Work in the Digital Economy: Sorting the Old from the New”. Working Paper 2016.03. Brussels: ETUI, 2016. 